\title{
Working with teacher and student voices: Towards developing a competency standard for a Filipino chemistry teacher
}

Espinosa, Allen A.

Philippine Normal University, Philippines (espinosa.aa@pnu.edu.ph)

Nueva España, Rebecca C.

Philippine Normal University, Philippines (nuevaespana.rc@pnu.edu.ph)

Datukan, Janir T.

Philippine Normal University, Philippines (datukan.jt@pnu.edu.ph)

Cortez, Leah Amor S.

Philippine Normal University, Philippines (cortez.las@pnu.edu.ph)

Tameta, Anna Danica C.

Philippine Normal University, Philippines (tameta.adc@pnu.edu.ph)

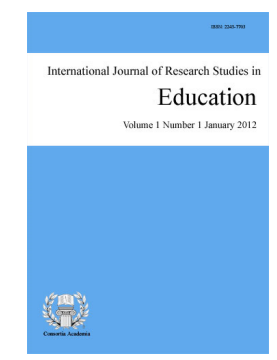

ISSN: 2243-7703 Online ISSN: 2243-7711

OPEN ACCESS

\section{Abstract}

With the aim of identifying competencies specific to a Filipino chemistry teacher, the present study surveyed and interviewed chemistry education academics and pre-service chemistry teachers across the Philippines. The results are divided into two: the primary competencies and the secondary competencies. The primary competency got the highest rating in the survey while the secondary competency got the second highest as agreed upon by the academics and the pre-service teachers. Results of aspect 1 show the importance of pedagogical content knowledge. In aspect 2, however, good knowledge on assessment of a teacher is deemed necessary. Aspect 3 deals with the ability of the teacher to vary his/her teaching strategy while aspect 4 recommends teachers to invest on professional development.

Keywords: pedagogical skills; performance assessment skills; classroom management skills professional development skills; chemistry teacher education 


\section{Working with teacher and student voices: Towards developing a competency standard for a Filipino chemistry teacher}

\section{Introduction}

Teachers in basic education acquire various skills and techniques in implementing classroom activities for an effective learning environment. Each subject requires a certain type of qualities that will enhance students' awareness and interest. In the context of this research, what then makes a competent chemistry teacher in basic education?

The Department of Education (2006) launched the National Competency-Based Teaching Standards or NCBTS to serve as a guide to Filipino teachers for effective teaching in the Philippines. It is an integrated theoretical framework that encompasses the various ways of teaching effectively, divided into several domains, including competencies required of any future teacher, specifically in the Philippine setting. It basically provides one framework that describes what effective teaching is, both in the developmental stages of a teacher and his professional growth and journey. In effect, it also serves as a guide for the preparation of teacher development programs, both on the locale of the teacher, i.e. the school where he is teaching in, and on the national level.

The framework of the NCBTS is divided into seven domains, namely: (1) Social Regard for Learning; (2) the Learning Environment; (3) the Diversity of Learners; (4) Curriculum; (5) Planning, Assessing, and Reporting; (6) Community Linkages; and (7) Personal Growth and Professional Development. Wide dissemination of the NCBTS was made possible through Department of Education (2009) Order No. 32, which spearheaded the nationwide campaign. In addition, the NCBTS was formulated through the initiative and efforts of the Teacher Education Council (TEC), which was created through the establishment of Republic Act No. 7784 in 1994. TEC was tasked to consolidate a long list of policies concerning teaching standards and to strengthen teacher education in the country. Furthermore, TEC was also requested to identify and establish Centers of Excellence (COE) in teacher education in various localities in the country that would help strengthen the training and education of pre-service teachers.

The NCBTS provides competencies for teacher education in general; however, it cannot be avoided that different disciplines will have different competency standards to be able to deliver the subject matter efficiently and effectively. The present study therefore proposes to explore the area of chemistry teacher education. The main purpose of the study is to develop a competency standard specific to chemistry teacher education. Specifically, it seeks to answer the following research questions:

$>$ What are the attributes of a competent chemistry teacher on the point of view of: chemistry education academics? and pre-service chemistry teachers?

$>$ What competency standard specific for chemistry teacher education can be formulated based from the results of the study?

\section{Literature Review}

\subsection{Teaching Competency Standards in Philippines}

A competent teacher is the one with the most significant elements of the country's education system. The competency of teachers was based on the standards known as NCBTS. The National Competency Based Teacher Standards of the Philippines is composed of seven domains as mandated by the Commission on Higher Education 
Working with teacher and student voices: Developing a competency standard for a Filipino chemistry teacher

or CHED (2007) Memorandum Order No. 52 on the Addendum to CHED (2004) Memorandum Order 30 entitled "Revised Policies and Standards for Undergraduate Teacher Education Curriculum".

Social Regard for Learning - The Domain Social Regard for Learning focuses on the ideal that teachers serve as positive and powerful role models of values of the pursuit of learning of different kinds of the effort to learn. The teacher's actions, statements and different types of social interactions with students exemplify this ideal.

\section{Teachers should:}

$>\quad$ Demonstrate value for learning.

Learning Environment - The Domain of Learning Environment focuses on importance of providing for a social, psychological and physical environment within which all benefits regardless of their individual differences in learning can engage the different learning activities and work towards attaining high standards of learning.

\section{Teachers should:}

$>\quad$ Create an environment that promotes fairness.

$>\quad$ Make the classroom environment safe and conducive to learning.

$>$ Communicate higher learning expectations to each learner.

D Establish and maintain consistent standards of learners' behavior.

Diversity of Learners - The domain of Diversity of Learners emphasized the ideal that teachers can facilitate the learning process in diverse learners by first recognizing and respecting individual differences, then using knowledge about students' differences to design diverse sets of learning activities to ensure that all students can attain desired learning goals.

\section{Teachers should:}

$>\quad$ Be familiar with learners' background knowledge and experiences.

$>$ Demonstrate concern for holistic development of learners.

Curriculum - The Domain of Curriculum refers to all elements of the teaching-learning process that work in convergence to help students understand the curricular goals and objectives, and to attain high standards of learning defined in the curriculum. These elements include the teacher's knowledge of subject matter and the learning process, teaching-learning approaches and activities, instructional materials and learning resources.

\section{Teachers should:}

$>$ Demonstrate mastery of the subject.

$>$ Communicate clear learning goals for the lessons that are appropriate for learners.

$>\quad$ Make good use of allotted instructional time.

$>\quad$ Selects teaching methods, learning activities and instructional materials or resources appropriate to learners and aligned to objectives of the lesson.

Planning, Assessing, and Reporting - The Domain of Planning, Assessing and Reporting refer to the alignment of assessment and planning activities. In particular, the domain focuses on the (1) use of assessment data to plan and revise teaching-learning plans, (2) the integration of assessment procedures in the plan and implementation of teaching-learning activities, and (3) reporting on learners' actual achievement and behavior. 


\section{Teachers should:}

$>\quad$ Develop and utilize creative and appropriate instructional plan.

$>\quad$ Develop and use a variety of appropriate assessment strategies to monitor and evaluate learning.

$>$ Monitor regularly and provide feedback on learners' understanding of content.

$>$ Communicate promptly and clearly to learners, parents and superiors about progress of learners.

Community Linkages - The Domain of Community Linkages focuses on the ideal that classroom activities are meaningfully linked to the experiences and aspirations of the students in their homes and communities. Thus the domain focuses on the teacher's' efforts directed at strengthening the links between schools and communities, particularly as these links help in the attainment of the curricular goals.

\section{Teachers should:}

$>$ Establish learning environments that respond to the aspirations of the community.

Personal Growth and Professional Development - The domain of Personal Growth and Professional Development emphasizes the ideal teachers' value having a high personal regard for the teaching profession, concern for professional development and continuous improvement as teachers.

\section{Teachers should:}

$>$ Take pride in the nobility of teaching as a profession.

$>$ Build professional linkages with their colleagues to improve their practice.

$>$ Reflect on the extent of their professional development goals.

\subsection{Developmental-National Competency-Based Teaching Standards (D-NCBTS)}

D-NCBTS is an on-going project of the Philippine National Research Center for Teacher Quality of the Philippine Normal University (2014). The project aims to prepare a set of development and teacher standards congruent with the $\mathrm{K}$ to 12 curriculums. D-NCBTS provides a basis for enhancing professional practice that targets pre-service and in-service teachers. The set standards aim to help these teachers in the progression of their career. The standard for validating D-NBTS is the current NCBTS that is used by teachers in all stages.

\subsection{Teacher Education and the ASEAN Integration}

The ASEAN education has changed rapidly within the years. ASEAN has an existing Education Strategic Plan based on the vision of the ASEAN Society which is a "Green and Happy Society" where people are given a morality-based knowledge and are strong enough to withstand the effects of globalization. In the last few years, the Southeast Asian countries have been concern with the coordination of international standards that facilitates both educational development goals and systems improvement within regions. Southeast Asian experts have identified a set of competencies through a Modified Developing a Curriculum (DACUM) Workshop. This includes:

$>$ Facilitating the development of learner's life and career skills.

$>\quad$ Creating a conductive learning environment.

$>$ Facilitating learning.

$>\quad$ Preparing appropriate lesson plans in line with the school vision and mission. 
$>$ Developing higher order thinking skills.

$>$ Developing and utilizing teaching and learning resources.

$>$ Enhancing ethical and moral value.

$>$ Assessing and evaluation learner performance.

$>$ Engaging in professional development.

$>$ Networking with stakeholders especially with parents.

> Managing student's welfare and other tasks.

The Southeast Asian countries successfully set the teacher competencies that cater not only those from the primary level but the higher levels as well. The provincial and local education authorities carry the responsibility of school supervision, curriculum and financial management. Thawatchai et al. (2014) identified the major characteristics of a competent teacher. The four attributes that were identified are related to: 1) pedagogical skills of teachers, 2) teacher performance assessment skills, 3) classroom management skills, and 4) professional development skills. The research also develops the Teaching Competency Standards in Higher Education (TCSHE) level for 6 universities in the ASEAN region. In the context of this research, we are using the ASEAN TCSHE in identifying competencies specific to a Filipino chemistry teacher.

In view of the literatures presented, figure 1 shows the conceptual framework of the study. The conceptual framework shows the general skills of a competent teacher in the ASEAN region - pedagogical skills, performance assessment skills, classroom management skills and professional development skills. A survey and a focus group were conducted among pre-service chemistry teachers and chemistry education academics to factor out outstanding indicators of each skill. This was the basis of the competency standard specific for chemistry teacher education that was developed.

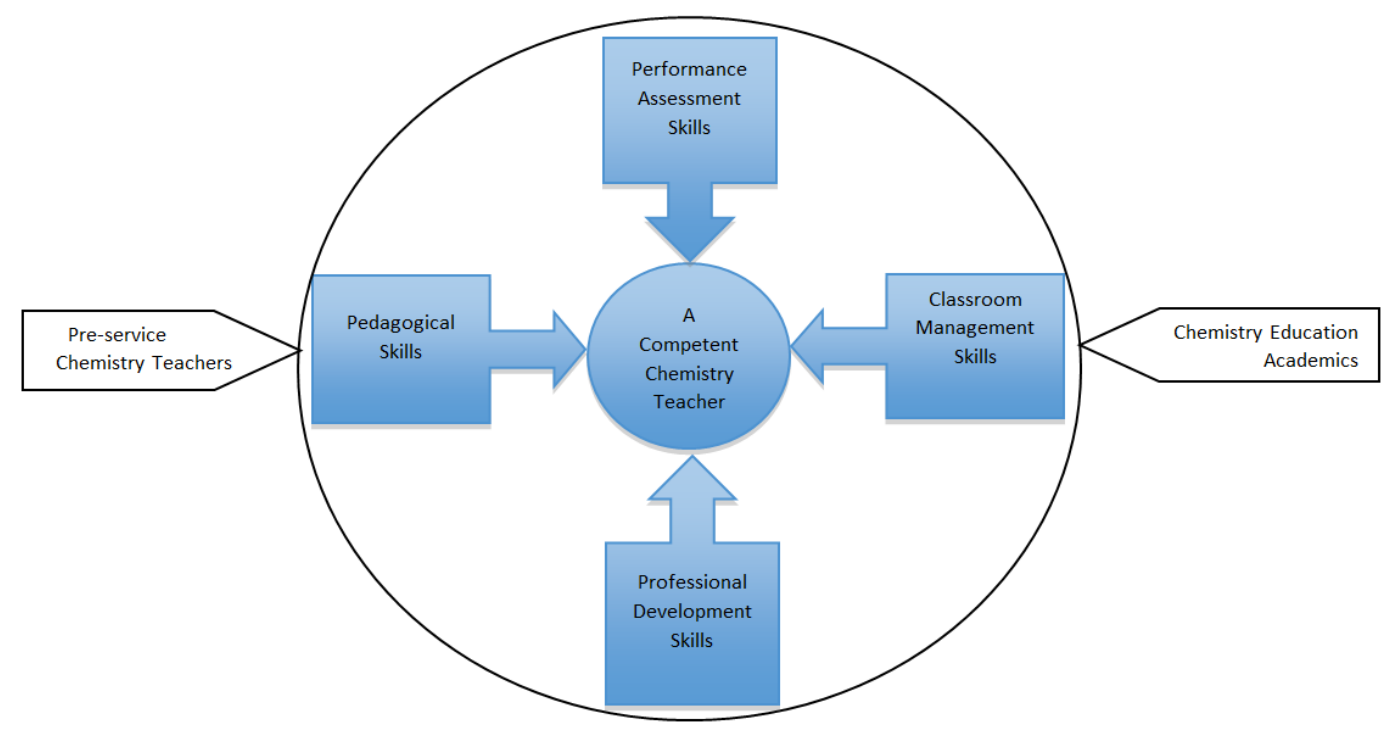

Figure 1. Conceptual Framework of the Study

\section{Methods}

\subsection{Research Design}

The study employed mixed methods study design. The quantitative survey method was used to identify 
Espinosa, A. A., Nueva España, R. C., Datukan, J. T., Cortez, L. A. S., \& Tameta, A. D. C.

outstanding indicators of pedagogical skills, performance assessment skills, classroom management skills and professional development skills of a competent chemistry teacher. The qualitative case study design, on the other hand, was used to conduct focus group among chemistry education academics and pre-service chemistry teachers. This was done to validate results of the survey. A competency standard specific to chemistry teacher education curriculum was then developed based from the results of the study.

\subsection{Participants}

Pre-service chemistry teachers and chemistry education academics from Teacher Education Institutions (TEI) from the National Capital region (NCR), Luzon, Visayas and Mindanao took part in the study. Detailed number of participants is found in table 1 below. Survey and focus group were conducted during the first and second semesters of school year 2015-2016.

Table 1

Participants of the Study

\begin{tabular}{|c|c|c|c|}
\hline Region & $\begin{array}{l}\text { Number of TEI } \\
\text { Participant }\end{array}$ & $\begin{array}{c}\text { Chemistry Education } \\
\text { Academic }\end{array}$ & $\begin{array}{c}\text { Pre-service Chemistry } \\
\text { Teacher }\end{array}$ \\
\hline National Capital Region & 1 & 2 & 5 \\
\hline Luzon & 1 & 3 & 6 \\
\hline Visayas & 1 & 3 & 3 \\
\hline Mindanao & 1 & 4 & 30 \\
\hline Total & & 12 & 44 \\
\hline
\end{tabular}

\subsection{Research Instruments}

Two research instruments were used in the study - the Student Questionnaire and the Teacher Questionnaire. The instruments were developed by a group of researchers from Suan Dusit Rajabhat University in Bangkok, Thailand for their study titled "Comparative Study and Development of Teaching Competency Standards in Higher Education Level between Faculty members and Senior Students among 5 ASEAN Universities Plus One (China)". Permission was given to the researchers to utilize and modify said instruments. The modified instruments were pilot tested to 94 students and 19 academics from a TEI in the NCR and has got a Cronbach alpha reliability coefficient of 0.8 and 0.7 respectively.

\subsection{Data Collection Procedure and Analysis}

Survey questionnaires were administered to pre-service chemistry teachers and chemistry education academics from Teacher Education Institutions (TEI) in the National Capital region (NCR), Luzon, Visayas and Mindanao. Focus group discussion among select pre-service chemistry teachers and chemistry education academics was also conducted to validate results of the survey. Data gathered were subjected to descriptive statistics to identify the outstanding indicators of a competent chemistry teacher for pedagogical skills, performance assessment skills, classroom management skills and professional development skills. Recorded interviews were transcribed and coded thematically. All names of participants are pseudonyms.

\section{Findings and Discussions}

The two instruments used in the study show the general attributes of a basic education teacher in the Association of Southeast Asian Nations (ASEAN) region. However, literature says that specific discipline requires specific teaching competency to be able to deliver the subject matter effectively and efficiently. Hence, with the aim of generalizing the competency standard in teaching chemistry in the basic education in the Philippines, we surveyed chemistry education academics and pre-service chemistry teachers in the National Capital Region (NCR), Luzon, Visayas and Mindanao. Each region is represented by a Teacher Education Institution (TEI) that is 
Working with teacher and student voices: Developing a competency standard for a Filipino chemistry teacher identified as Center of Excellence (COE) by the Commission on Higher Education (CHED). Results of the survey are outlined in tables 2, 3, 4 and 5 .

Table 2 shows the comparison between the perception of chemistry education academics and pre-service chemistry teachers on Aspect 1 (lecturer's pedagogical skills). Apparently, for both sectors, there are two primary competencies that falls under this category: (2) The lecturer is competent to his/her subject area $[M=0.667$, $S D=2.21$ and $M=0.841, S D=5.51$ ]; and (6) The lecturer is well informed on all parts of the course being taught $[M=0.667, S D=2.21$ and $M=0.841, S D=5.51]$. Seemingly, both sectors find the teacher's pedagogical content knowledge or PCK very important to be a competent chemistry teacher. These attributes are also reflected during the focus group with academics and pre-service teachers. As Jessica (an academic) commented on being competent on the subject area ... of course if you are teaching certain subjects, say chemistry, it is very important for you to know the subject matter.. The same thing transpired when asked about being well informed on all parts of the course. Monica's (a pre-service teacher) remark about it is that "it is very important that a lecturer possess broad knowledge in teaching the course because that will be a reason for him to be effective in teaching the students".

\section{Table 2}

Lecturer's Pedagogical Skills

\begin{tabular}{|c|c|c|c|c|c|c|c|c|c|}
\hline \multicolumn{2}{|c|}{ Aspect 1: Lecturer's Pedagogical Skills } & \multicolumn{4}{|c|}{ Academics } & \multicolumn{4}{|c|}{ Pre-Service Teachers } \\
\hline \multicolumn{2}{|c|}{ The lecturer... } & $\begin{array}{l}\text { Highest } \\
\text { response* }\end{array}$ & $\mathrm{n}=12$ & Mean & $\mathrm{SD}$ & $\begin{array}{l}\text { Highest } \\
\text { response* }\end{array}$ & $\mathrm{n}=44$ & Mean & SD \\
\hline 1 & patiently listens to his or her students. & 3 & 7 & 0.583 & 1.93 & 4 & 37 & 0.841 & 5.51 \\
\hline 2 & is competent to his/her subject area. & 4 & 8 & 0.667 & 2.21 & 4 & 37 & 0.841 & 5.51 \\
\hline 3 & $\begin{array}{l}\text { is aware of general goals, policies, and regulations } \\
\text { of higher education. }\end{array}$ & 4 & 7 & 0.583 & 1.93 & 4 & 33 & 0.750 & 4.92 \\
\hline 4 & has good curriculum knowledge and understanding. & 4 & 8 & 0.667 & 2.21 & 4 & 35 & 0.795 & 5.22 \\
\hline 5 & $\begin{array}{l}\text { let's student participate in the discussion within } \\
\text { their learning goals and framework. }\end{array}$ & 4 & 8 & 0.667 & 2.21 & 4 & 35 & 0.795 & 5.22 \\
\hline 6 & $\begin{array}{l}\text { is well informed on all parts of the course being } \\
\text { taught. }\end{array}$ & 4 & 8 & 0.667 & 2.21 & 4 & 37 & 0.841 & 5.51 \\
\hline 7 & $\begin{array}{l}\text { explains to students how this course relates with } \\
\text { their majorship. }\end{array}$ & 4 and 3 & 6 & 0.500 & 1.66 & 4 & 33 & 0.750 & 4.92 \\
\hline 8 & $\begin{array}{l}\text { coordinates with other course teachers on how the } \\
\text { course is being taught/handled. }\end{array}$ & 3 & 7 & 0.583 & 1.93 & 4 & 33 & 0.750 & 4.92 \\
\hline 9 & develops the course and its teaching activities. & 4 & 6 & 0.500 & 1.66 & 4 & 35 & 0.795 & 5.22 \\
\hline 10 & stands out as a leader in pedagogical activities. & 4 & 8 & 0.667 & 2.21 & 4 & 33 & 0.750 & 4.92 \\
\hline 11 & $\begin{array}{l}\text { draws a connection between the content of the field } \\
\text { to related fields. }\end{array}$ & 4 and 3 & 6 & 0.500 & 1.66 & 4 & 37 & 0.841 & 5.51 \\
\hline 12 & $\begin{array}{l}\text { share skills and experiences in the development and } \\
\text { improvement of the program. }\end{array}$ & 4 and 3 & 6 & 0.500 & 1.66 & 4 & 33 & 0.750 & 4.92 \\
\hline 13 & $\begin{array}{l}\text { adjusts his/her personality according to the needs of } \\
\text { the course. }\end{array}$ & 4 and 3 & 6 & 0.500 & 1.66 & 4 & 35 & 0.795 & 5.22 \\
\hline 14 & $\begin{array}{l}\text { adapts when circumstances change and offers } \\
\text { viable alternative approaches. }\end{array}$ & 4 & 6 & 0.500 & 1.66 & 4 & 37 & 0.841 & 5.51 \\
\hline 15 & is abreast with latest developments in the field. & 4 & 7 & 0.583 & 1.93 & 4 & 37 & 0.841 & 5.51 \\
\hline 16 & $\begin{array}{l}\text { makes the students focal point when planning the } \\
\text { course. }\end{array}$ & 4 & 7 & 0.583 & 1.93 & 4 & 33 & 0.750 & 4.92 \\
\hline 17 & $\begin{array}{l}\text { helps students develop critical thinking and } \\
\text { reflective attitude. }\end{array}$ & 4 & 8 & 0.667 & 2.21 & 4 & 35 & 0.795 & 5.22 \\
\hline 18 & possesses broad knowledge in the teaching course. & 4 & 8 & 0.667 & 2.21 & 4 & 35 & 0.795 & 5.22 \\
\hline 19 & is up-to-date with all aspects of the course. & 4 & 8 & 0.667 & 2.21 & 4 & 35 & 0.795 & 5.22 \\
\hline 20 & provides an overview of the course content. & 4 & 7 & 0.583 & 1.93 & 4 & 35 & 0.795 & 5.22 \\
\hline 21 & is appreciated by the students. & 4 and 3 & 6 & 0.500 & 1.66 & 4 & 33 & 0.750 & 4.92 \\
\hline 22 & is appreciated as a leader of pedagogical activities. & 4 and 3 & 6 & 0.500 & 1.66 & 4 & 35 & 0.795 & 5.22 \\
\hline 23 & $\begin{array}{l}\text { supports students in their learning process by } \\
\text { addressing and responding to their questions and } \\
\text { problems. }\end{array}$ & 4 & 8 & 0.667 & 2.21 & 4 & 35 & 0.795 & 5.22 \\
\hline
\end{tabular}

For the identified secondary competencies needed by a competent chemistry teacher, both sectors choses: (1) The lecturer patiently listens to his or her students $[M=0.583, S D=1.93$ and $M=0.841$ and $S D=5.51]$; (4) The lecturer has good curriculum knowledge and understanding $[M=0.667, S D=2.21$ and $M=0795, S D=5.22]$; (15) The 
Espinosa, A. A., Nueva España, R. C., Datukan, J. T., Cortez, L. A. S., \& Tameta, A. D. C.

lecturer is abreast with latest developments in the field $[M=0.583, S D=1.93$ and $M=0.841$ and $S D=5.51]$; (17) The lecturer helps students develop critical thinking and reflective attitude $[M=0.667, S D=2.21$ and $M=0795, S D=5.22$; (18) The lecturer possesses broad knowledge in the teaching course $[M=0.667, S D=2.21$ and $M=0795, S D=5.22]$; (19) The lecturer is up-to-date with all aspects of the course [ $M=0.667, S D=2.21$ and $M=0795, S D=5.22]$; and (23) The lecturer supports students in their learning process by addressing and responding to their questions and problems [ $M=0.667, S D=2.21$ and $M=0795, S D=5.22]$.

Table 3 shows the comparison between the perception of chemistry education academics and pre-service chemistry teachers on Aspect 2 (student's performance assessment skills). In this category, academics and pre-service teachers have different perception on the primary competency needed by a basic education chemistry teacher. The academics identified three primary competencies: (1) The lecturer provides clear information on students' performance [ $M=0.750, S D=2.49]$; (13) The lecturer presents students' tasks clearly and what support they can expect $[M=0.750, S D=2.49]$; and (14) The lecturer is responsible for the tasks assigned to the student $[M=0.750, S D=2.49]$. The pre-service teachers, on the other hand, have also identified three primary competencies. These are: (3) The lecturer uses a variety of assessment tools and methods [ $M=0.841, S D=5.51]$; (15) The lecturer is open to different ideas and perspectives $[M=0.841, S D=5.51]$; and (19) The lecturer takes into consideration students' previous knowledge and background $[M=0.841, S D=5.51]$. Since they did not agree on the highest competency, we did not consider this. Instead, we look into the second highest where both sectors agreed.

Looking at the second highest competencies, we found out that the competencies agreed upon by both chemistry education academics and pre-service chemistry teachers under this category are the following: (1) The lecturer provides clear information on students' performance $[M=0.750, S D=2.49, M=0.818, S D=5.37]$; (3) The lecturer uses a variety of assessment tools and methods $[M=0.667, S D=2.21, M=0.841, S D=5.51]$; (14) The lecturer is responsible for the tasks assigned to the student $[M=0.750, S D=2.49, M=0.818, S D=5.37]$; and (15) The lecturer is open to different ideas and perspectives $[M=0.667, S D=2.21, M=0.841, S D=5.51]$. We considered these competencies as primary as they are the highest competencies agreed upon by both sectors.

When asked why they chose competency 1, Sasha (a pre-service teacher) said "the students should know their standing in the class so that they know what to focus on and how to catch up in the subject". On competency 15 , Amber (a pre-service teacher) commented that "even though we are teachers, we can also learn from our students". Apparently, the survey gives a high rating for competencies 3 and 14 but it did not transpire during the focus group with both the academics and pre-service teachers. A follow up discussion is hereby recommended for future studies.

Table 3

Student's Performance Assessment Skills

\begin{tabular}{|c|c|c|c|c|c|c|c|c|c|}
\hline \multicolumn{2}{|r|}{ Aspect 2: Students' Performance Assessment Skills } & \multicolumn{4}{|c|}{ Academics } & \multicolumn{4}{|c|}{ Pre-Service Teachers } \\
\hline \multicolumn{2}{|c|}{ The Lecturer... } & $\begin{array}{l}\text { Highest } \\
\text { response* }\end{array}$ & $\mathrm{n}=12$ & Mean & SD & $\begin{array}{l}\text { Highest } \\
\text { response* }\end{array}$ & $\mathrm{n}=44$ & Mean & SD \\
\hline 1 & provides clear information on students' performance. & 4 & 9 & 0.750 & 2.49 & 4 & 36 & 0.818 & 5.37 \\
\hline 2 & gives prompt feedback. & 4 & 8 & 0.667 & 2.21 & 4 & 36 & 0.818 & 5.37 \\
\hline 3 & uses a variety of assessment tools and methods. & 4 & 8 & 0.667 & 2.21 & 4 & 37 & 0.841 & 5.51 \\
\hline 4 & $\begin{array}{l}\text { discusses students' assessment and performance with } \\
\text { fellow teachers and immediate supervisor. }\end{array}$ & 4 and 3 & 6 & 0.500 & 1.66 & 4 & 34 & 0.773 & 5.07 \\
\hline 5 & $\begin{array}{l}\text { discusses students' assessment and performance with } \\
\text { them. }\end{array}$ & 4 & 7 & 0.583 & 1.93 & 4 & 36 & 0.818 & 5.37 \\
\hline 6 & $\begin{array}{l}\text { discusses the results of students' assessment and } \\
\text { performance with their parents. }\end{array}$ & 4 and 3 & 6 & 0.500 & 1.66 & 4 & 35 & 0.795 & 5.22 \\
\hline 7 & $\begin{array}{l}\text { put course evaluations by students to meaningful } \\
\text { use. }\end{array}$ & 4 and 3 & 6 & 0.500 & 1.66 & 4 & 36 & 0.818 & 5.37 \\
\hline 8 & develops evaluation tools. & 4 and 3 & 6 & 0.500 & 1.66 & 4 & 36 & 0.818 & 5.37 \\
\hline 9 & discusses the evaluation tools with the students. & 4 & 7 & 0.583 & 1.93 & 4 & 36 & 0.818 & 5.37 \\
\hline 10 & $\begin{array}{l}\text { analyses learning problems (general or field } \\
\text { specific) and responds to these. }\end{array}$ & 4 and 3 & 6 & 0.500 & 1.66 & 4 & 36 & 0.818 & 5.37 \\
\hline
\end{tabular}


Table 3 ... continued

\begin{tabular}{|c|c|c|c|c|c|c|c|c|c|}
\hline \multicolumn{2}{|r|}{ Aspect 2: Students' Performance Assessment Skills } & \multicolumn{4}{|c|}{ Academics } & \multicolumn{4}{|c|}{ Pre-Service Teachers } \\
\hline \multicolumn{2}{|c|}{ The Lecturer... } & $\begin{array}{l}\text { Highest } \\
\text { response* }\end{array}$ & $\mathrm{n}=12$ & Mean & SD & $\begin{array}{l}\text { Highest } \\
\text { response* }\end{array}$ & $\mathrm{n}=44$ & Mean & SD \\
\hline 11 & $\begin{array}{l}\text { uses current and up-to-date assessment approaches } \\
\text { in the field. }\end{array}$ & 4 & 7 & 0.583 & 1.93 & 4 & 36 & 0.818 & 5.37 \\
\hline 12 & $\begin{array}{l}\text { applies rules consistently and lives up to the } \\
\text { assessment methods used in the course. }\end{array}$ & 4 & 8 & 0.667 & 2.21 & 4 & 36 & 0.818 & 5.37 \\
\hline 13 & $\begin{array}{l}\text { presents students' tasks clearly and what support } \\
\text { they can expect. }\end{array}$ & 4 & 9 & 0.750 & 2.49 & 4 & 35 & 0.795 & 5.22 \\
\hline 14 & is responsible for the tasks assigned to the student. & 4 & 9 & 0.750 & 2.49 & 4 & 36 & 0.818 & 5.37 \\
\hline 15 & is open to different ideas and perspectives. & 4 & 8 & 0.667 & 2.21 & 4 & 37 & 0.841 & 5.51 \\
\hline 16 & $\begin{array}{l}\text { practices professional conduct and expresses the } \\
\text { values, norms, and pedagogical approaches. }\end{array}$ & 4 and 3 & 6 & 0.500 & 1.66 & 4 & 36 & 0.818 & 5.37 \\
\hline 17 & $\begin{array}{l}\text { is familiar with a variety of evaluation and } \\
\text { assessment methods. }\end{array}$ & 4 & 8 & 0.667 & 2.21 & 4 & 36 & 0.818 & 5.37 \\
\hline 18 & $\begin{array}{l}\text { reflects on personal behavior systematically and } \\
\text { considers feedback from others when doing so. }\end{array}$ & 4 & 7 & 0.583 & 1.93 & 4 & 35 & 0.795 & 5.22 \\
\hline 19 & $\begin{array}{l}\text { takes into consideration students' previous } \\
\text { knowledge and background. }\end{array}$ & 4 & 7 & 0.583 & 1.93 & 4 & 37 & 0.841 & 5.51 \\
\hline 20 & $\begin{array}{l}\text { recognizes students' behavioral problems and } \\
\text { addresses these. }\end{array}$ & 4 & 7 & 0.583 & 1.93 & 4 & 35 & 0.795 & 5.22 \\
\hline
\end{tabular}

Note. *Response: 4 - Very Important; 3 - Slightly Important; 2 - Important; 1 - Not Important

The secondary competencies under this category are the following: (2) The lecturer gives prompt feedback $[M=0.667, S D=2.21, M=0.818, S D=5.37]$; (12) The lecturer applies rules consistently and lives up to the assessment methods used in the course [ $M=0667, S D=2.21$ and $M=0.818, S D=5.37]$; (17) The lecturer is familiar with a variety of evaluation and assessment methods [ $M=0.667, S D=2.21$ and $M=0.818, S D=5.37]$.

The comparison between chemistry education academics and pre-service chemistry teachers in terms of Aspect 3 (classroom management skills) is shown in table 4 below. It is quite obvious that both sectors have chosen different primary competencies needed to be a successful chemistry teacher in the basic education. For chemistry education academics, they have chosen the following: (8) The lecturer is familiar with different parts of teaching-learning process $[M=0.750, S D=2.49]$; (12) The lecturer is adept with different teaching strategies $[M=0.750, S D=2.49]$; (23) The lecturer uses written, audio-visual, and digital teaching aids to achieve the teaching goals $[M=0.750, S D=2.49]$; and (25) The lecturer uses students' previous knowledge and connects these to their experiences and interests $[M=0.750, S D=2.49]$.

On the other hand, for pre-service chemistry teachers, the following are important to them: (6) The lecturer continually develops knowledge about the subject being taught $[M=1.00, S D=6.56]$; (10) The lecturer varies teaching methods and content according to available resources $[M=1.00, S D=6.56]$; (13) The lecturer varies teaching strategies according to students' needs $[M=1.00, S D=6.56]$; (17) The lecturer ensures a learning environment where students can contribute their own inputs $[M=1.00, S D=6.56]$; (22) The lecturer develops different learning strategies to respond to students' learning style differences $[M=1.00, S D=6.56]$; (24) The lecturer adapts existing materials and expands these based on questions, suggestions, and examples from students $[M=1.00$, $S D=6.56]$; (26) The lecturer employs different methods that recognize students' differences such as their different ways of learning, different levels, and different ways of working [M=1.00, $S D=6.56]$; (28) The lecturer makes the content, form, structures, and relevance of the learning activity clear $[M=1.00, S D=6.56]$; (29) The lecturer encourages students' cooperation and participation $[M=1.00, S D=6.56]$; and (30) The lecturer develops both individual and group activities $[M=1.00, S D=6.56]$. But since they did not agree on the highest competency for this category, we did not consider this as a primary competency. Instead, we look into the second highest where both sectors agreed. 
Espinosa, A. A., Nueva España, R. C., Datukan, J. T., Cortez, L. A. S., \& Tameta, A. D. C.

\section{Table 4}

Classroom Management Skills

\begin{tabular}{|c|c|c|c|c|c|c|c|c|c|}
\hline \multicolumn{2}{|c|}{ Aspect 3: Students' Performance Assessment Skills } & \multicolumn{4}{|c|}{ Academics } & \multicolumn{4}{|c|}{ Pre-Service Teachers } \\
\hline \multicolumn{2}{|c|}{ The Lecturer... } & $\begin{array}{l}\text { Highest } \\
\text { response* }\end{array}$ & $\mathrm{n}=12$ & Mean & SD & $\begin{array}{c}\text { Highest } \\
\text { response* }\end{array}$ & $\mathrm{n}=44$ & Mean & SD \\
\hline 1 & $\begin{array}{l}\text { provides clear information on students' } \\
\text { performance. }\end{array}$ & 4 & 9 & 0.750 & 2.49 & 4 & 36 & 0.818 & 5.37 \\
\hline 2 & gives prompt feedback. & 4 & 8 & 0.667 & 2.21 & 4 & 36 & 0.818 & 5.37 \\
\hline 3 & $\begin{array}{l}\text { uses a variety of assessment tools and } \\
\text { methods. }\end{array}$ & 4 & 8 & 0.667 & 2.21 & 4 & 37 & 0.841 & 5.51 \\
\hline 4 & $\begin{array}{l}\text { discusses students' assessment and } \\
\text { performance with fellow teachers and } \\
\text { immediate supervisor. }\end{array}$ & 4 and 3 & 6 & 0.500 & 1.66 & 4 & 34 & 0.773 & 5.07 \\
\hline 5 & $\begin{array}{l}\text { discusses students' assessment and } \\
\text { performance with them. }\end{array}$ & 4 & 7 & 0.583 & 1.93 & 4 & 36 & 0.818 & 5.37 \\
\hline 6 & $\begin{array}{l}\text { discusses the results of students' assessment } \\
\text { and performance with their parents. }\end{array}$ & 4 and 3 & 6 & 0.500 & 1.66 & 4 & 35 & 0.795 & 5.22 \\
\hline 7 & $\begin{array}{l}\text { put course evaluations by students to } \\
\text { meaningful use. }\end{array}$ & 4 and 3 & 6 & 0.500 & 1.66 & 4 & 36 & 0.818 & 5.37 \\
\hline 8 & develops evaluation tools. & 4 and 3 & 6 & 0.500 & 1.66 & 4 & 36 & 0.818 & 5.37 \\
\hline 9 & $\begin{array}{l}\text { discusses the evaluation tools with the } \\
\text { students. }\end{array}$ & 4 & 7 & 0.583 & 1.93 & 4 & 36 & 0.818 & 5.37 \\
\hline 10 & $\begin{array}{l}\text { analyses learning problems (general or field } \\
\text { specific) and responds to these. }\end{array}$ & 4 and 3 & 6 & 0.500 & 1.66 & 4 & 36 & 0.818 & 5.37 \\
\hline 11 & $\begin{array}{l}\text { uses current and up-to-date assessment } \\
\text { approaches in the field. }\end{array}$ & 4 & 7 & 0.583 & 1.93 & 4 & 36 & 0.818 & 5.37 \\
\hline 12 & $\begin{array}{l}\text { applies rules consistently and lives up to the } \\
\text { assessment methods used in the course. }\end{array}$ & 4 & 8 & 0.667 & 2.21 & 4 & 36 & 0.818 & 5.37 \\
\hline 13 & $\begin{array}{l}\text { presents students' tasks clearly and what } \\
\text { support they can expect. }\end{array}$ & 4 & 9 & 0.750 & 2.49 & 4 & 35 & 0.795 & 5.22 \\
\hline 14 & $\begin{array}{l}\text { is responsible for the tasks assigned to the } \\
\text { student. }\end{array}$ & 4 & 9 & 0.750 & 2.49 & 4 & 36 & 0.818 & 5.37 \\
\hline 15 & is open to different ideas and perspectives. & 4 & 8 & 0.667 & 2.21 & 4 & 37 & 0.841 & 5.51 \\
\hline 16 & $\begin{array}{l}\text { practices professional conduct and expresses } \\
\text { the values, norms, and pedagogical } \\
\text { approaches. }\end{array}$ & 4 and 3 & 6 & 0.500 & 1.66 & 4 & 36 & 0.818 & 5.37 \\
\hline 17 & $\begin{array}{l}\text { is familiar with a variety of evaluation and } \\
\text { assessment methods. }\end{array}$ & 4 & 8 & 0.667 & 2.21 & 4 & 36 & 0.818 & 5.37 \\
\hline 18 & $\begin{array}{l}\text { reflects on personal behavior systematically } \\
\text { and considers feedback from others when } \\
\text { doing so. }\end{array}$ & 4 & 7 & 0.583 & 1.93 & 4 & 35 & 0.795 & 5.22 \\
\hline 19 & $\begin{array}{l}\text { takes into consideration students' previous } \\
\text { knowledge and background. }\end{array}$ & 4 & 7 & 0.583 & 1.93 & 4 & 37 & 0.841 & 5.51 \\
\hline 20 & $\begin{array}{l}\text { recognizes students' behavioral problems and } \\
\text { addresses these. }\end{array}$ & 4 & 7 & 0.583 & 1.93 & 4 & 35 & 0.795 & 5.22 \\
\hline
\end{tabular}

Note. *Response: 4 - Very Important; 3 - Slightly Important; 2 - Important; 1 - Not Important

The competencies where both sectors agreed are as follows: (8) The lecturer is familiar with different parts of teaching-learning process $[M=0.750, S D=2.49$ and $M=0.977, S D=6.41]$; (10) The lecturer varies teaching methods and content according to available resources $[M=0.667, S D=2.21$ and $M=1.00, S D=6.56]$; (17) The lecturer ensures a learning environment where students can contribute their own inputs $[M=0.667, S D=2.21$ and $M=1.00, S D=6.56]$; (22) The lecturer develops different learning strategies to respond to students' learning style differences $[M=0.667$, $S D=2.21$ and $M=1.00, S D=6.56]$; (23) The lecturer uses written, audio-visual, and digital teaching aids to achieve the teaching goals $[M=0.750, S D=2.49$ and $M=0977, S D=6.41]$; (24) The lecturer adapts existing materials and expands these based on questions, suggestions, and examples from students $[M=0.667, S D=2.21$ and $M=1.00$, $S D=6.56]$; (26) The lecturer employs different methods that recognize students' differences such as their different ways of learning, different levels, and different ways of working $[M=0.667, S D=2.21$ and $M=1.00, S D=6.56]$; (28) The lecturer makes the content, form, structures, and relevance of the learning activity clear $[M=0.667, S D=2.21$ and $M=1.00, S D=6.56]$; and (29) The lecturer encourages students' cooperation and participation $[M=0.667$, $S D=2.21$ and $M=1.00, S D=6.56]$.

Eunice (a pre-service teacher) said that competency 10 is an important attribute: "We should maximize whatever resources we have and we should not always depend on technology". Joseph (an academic), on the other hand, commented on competency 22 , he said: "I think that the lecturer ... especially if you are a chemistry teacher, 
Working with teacher and student voices: Developing a competency standard for a Filipino chemistry teacher because chemistry is so abstract... is familiar with ... different styles”. Moreover, Jay (a pre-service teacher) said that competency 23 is important "...because it will help make a conducive environment for students". Anisha, another pre-service teacher seconded on competency 23 saying that "sometimes our students get bored with routinary presentation of lessons, so it is important if we use variety of teaching strategies to keep them motivated and to keep them focus on the lesson”. Competencies 8, 17, 24, 26, 28 and 29 got a high rating in the survey but it did not transpire during the focus group. It is recommended for future study to conduct focus group on both sectors why they chose those competencies.

The secondary competencies chosen by both sectors are: (4) The lecturer is familiar with and considers students' different learning styles [ $M=0.667, S D=2.21$ and $M=0.977, S D=6.41]$; (7) The lecturer is familiar with the requirements of the course and applies various teaching methods [ $M=0.667, S D=2.21$ and $M=0.977, S D=6.41]$; and (20) The lecturer challenges students to think about their own learning and development $[M=0.667, S D=2.21$ and $M=0977, S D=6.41]$.

Shown in table 5 is the comparison in Aspect 4 (professional development skills) between chemistry education academics and pre-service chemistry teachers. The two sectors have a different perception on what competency is needed to be successful chemistry teacher under this category. For chemistry education academics, the most important is (13) The lecturer participates in various teacher training courses $[M=0.750, S D=2.49]$. However, for pre-service chemistry teachers, the most important is (4) The lecturer has a clear concept of the role and responsibilities of the student and the teacher [ $M=0.886, S D=5.81]$.

\section{Table 5}

Professional Development Skills

\begin{tabular}{|c|c|c|c|c|c|c|c|c|c|}
\hline \multirow{2}{*}{\multicolumn{2}{|c|}{ Aspect 4: Professional Development Skills }} & \multirow{2}{*}{\multicolumn{4}{|c|}{ Academics }} & \multirow{2}{*}{\multicolumn{4}{|c|}{ Pre-Service Teachers }} \\
\hline & & & & & & & & & \\
\hline The & Lecturer. & \multirow{2}{*}{$\begin{array}{c}\begin{array}{c}\text { Highest } \\
\text { response* }\end{array} \\
4\end{array}$} & \multirow{2}{*}{$\frac{\mathrm{n}=12}{7}$} & \multirow{2}{*}{$\begin{array}{l}\text { Mean } \\
0.583\end{array}$} & \multirow{2}{*}{$\begin{array}{c}\text { SD } \\
1.93\end{array}$} & \multirow{2}{*}{$\begin{array}{c}\begin{array}{c}\text { Highest } \\
\text { response* }\end{array} \\
4\end{array}$} & \multirow{2}{*}{$\begin{array}{c}\mathrm{n}=44 \\
36\end{array}$} & \multirow{2}{*}{$\begin{array}{l}\text { Mean } \\
0.818\end{array}$} & \multirow{2}{*}{$\begin{array}{r}\text { SD } \\
5.37\end{array}$} \\
\hline 1 & $\begin{array}{l}\text { develops knowledge continuously by attending } \\
\text { academic conferences or pedagogical courses. }\end{array}$ & & & & & & & & \\
\hline 2 & $\begin{array}{l}\text { stimulates pedagogical development and discussions } \\
\text { on teaching. }\end{array}$ & 4 & 7 & 0.583 & 1.93 & 4 & 30 & 0.682 & 4.47 \\
\hline 3 & $\begin{array}{l}\text { attends and presents in academic conferences both } \\
\text { in the national and international levels. }\end{array}$ & 4 & 8 & 0.667 & 2.21 & 4 & 29 & 0.659 & 4.32 \\
\hline 4 & $\begin{array}{l}\text { has a clear concept of the role and responsibilities of } \\
\text { the student and the teacher. }\end{array}$ & 4 and 3 & 6 & 0.500 & 1.66 & 4 & 39 & 0.886 & 5.81 \\
\hline 5 & $\begin{array}{l}\text { informs students on the reasons for choosing } \\
\text { teaching as a profession. }\end{array}$ & 4 & 7 & 0.583 & 1.93 & 4 & 25 & 0.568 & 3.73 \\
\hline 6 & $\begin{array}{l}\text { develops teaching strategies that gives the best } \\
\text { support to students' learning based on research. }\end{array}$ & 4 & 7 & 0.583 & 1.93 & 4 & 30 & 0.682 & 4.47 \\
\hline 7 & $\begin{array}{l}\text { links teaching strategies to present research findings } \\
\text { within the subject area. }\end{array}$ & 4 & 7 & 0.583 & 1.93 & 4 & 31 & 0.705 & 4.62 \\
\hline 8 & $\begin{array}{l}\text { continuously updates pedagogical content } \\
\text { knowledge in the subject area. }\end{array}$ & 4 & 7 & 0.583 & 1.93 & 4 & 33 & 0.750 & 4.92 \\
\hline 9 & $\begin{array}{l}\text { seeks additional information on the subject being } \\
\text { taught by reading journals or attending conferences. }\end{array}$ & 4 & 7 & 0.583 & 1.93 & 4 & 36 & 0.818 & 5.37 \\
\hline 10 & $\begin{array}{l}\text { coordinates between different course sections and } \\
\text { teachers. }\end{array}$ & 4 and 3 & 6 & 0.500 & 1.66 & 4 & 28 & 0.636 & 4.17 \\
\hline 11 & works well with other teachers and personnel. & 4 & 7 & 0.583 & 1.93 & 4 & 32 & 0.727 & 4.77 \\
\hline 12 & $\begin{array}{l}\text { engages in educational advancement and } \\
\text { development. }\end{array}$ & 4 & 8 & 0.667 & 2.21 & 4 & 35 & 0.795 & 5.22 \\
\hline 13 & participates in various teacher training courses. & 4 & 9 & 0.750 & 2.49 & 4 & 35 & 0.795 & 5.22 \\
\hline 14 & $\begin{array}{l}\text { writes about teaching and publishes in educational } \\
\text { journals. }\end{array}$ & 4 & 8 & 0.667 & 2.21 & 4 & 23 & 0.523 & 3.43 \\
\hline 15 & $\begin{array}{l}\text { shares teaching experiences and educational } \\
\text { researches in conferences and colloquia. }\end{array}$ & 4 and 3 & 6 & 0.500 & 1.66 & 4 & 29 & 0.659 & 4.32 \\
\hline 16 & $\begin{array}{l}\text { assumes leadership roles in professional } \\
\text { organizations and carries out responsibilities, with } \\
\text { good results. }\end{array}$ & 4 & 8 & 0.667 & 2.21 & 4 & 29 & 0.659 & 4.32 \\
\hline 17 & $\begin{array}{l}\text { communicates ideas, practices, and experiences } \\
\text { clearly and effectively with students, personnel, and } \\
\text { other teacher. }\end{array}$ & 4 and 3 & 6 & 0.500 & 1.66 & 4 & 36 & 0.818 & 5.37 \\
\hline 18 & $\begin{array}{l}\text { acts as an effective counsellor to students, when } \\
\text { necessary. }\end{array}$ & 4 and 3 & 6 & 0.500 & 1.66 & 4 & 30 & 0.682 & 4.47 \\
\hline
\end{tabular}


Since the two sectors did not agree on the most needed competency, we looked into the second and third highest ratings. We then considered these to be the primary competencies as agreed upon by both sectors. These are: (1) The lecturer develops knowledge continuously by attending academic conferences or pedagogical courses $[M=0.583, S D=1.93$ and $M=0.818, S D=5.37]$; (9) The lecturer seeks additional information on the subject being taught by reading journals or attending conferences [ $M=0.583, S D=1.93$ and $M=0.818, S D=5.37]$; (12) The lecturer engages in educational advancement and development $[M=0.667, S D=2.21$ and $M=0.795, S D=5.22]$; and (13) The lecturer participates in various teacher training courses $[M=0750, S D=2.49$ and $M=0.795, S D=5.22]$. We do not have secondary competencies for this category as we have already looked into the second and third highest ratings.

Jenny (an academic) said that competency 1 is important because: "we are able to also develop our [pre-service] teachers based on what we have learned in the school". Moreover, competency 12 is important because "when you are inside the classroom, you can share your experience to your students ... [by] participating in ... conference" said Joseph (an academic). Again, competencies 9 and 13 got a high rating in the survey but it did not transpire during the focus group. It is hereby recommended that future researchers conduct a focus group on both sectors regarding the aforementioned competencies.

In view of the perceptions of chemistry education academics and pre-service chemistry teachers in different regions of the Philippines, the following competency standard is suggested to be included in the curriculum for a holistic Filipino chemistry teacher education:

\section{Aspect 1: Lecturer's Pedagogical Skills}

\section{Primary Competencies}

$>\quad$ The lecturer is competent to his/her subject area.

$>\quad$ The lecturer is well informed on all parts of the course being taught.

\section{Secondary Competencies}

$>$ The lecturer patiently listens to his or her students.

$>\quad$ The lecturer has good curriculum knowledge and understanding.

$>$ The lecturer is abreast with latest developments in the field.

$>\quad$ The lecturer helps students develop critical thinking and reflective attitude.

$>\quad$ The lecturer possesses broad knowledge in the teaching course.

$>\quad$ The lecturer is up-to-date with all aspects of the course.

$>\quad$ The lecturer supports students in their learning process by addressing and responding to their questions and problems.

\section{Aspect 2: Student's Performance Assessment Skills}

\section{Primary Competencies}

$>\quad$ The lecturer provides clear information on students' performance.

$>\quad$ The lecturer uses a variety of assessment tools and methods.

$>\quad$ The lecturer is responsible for the tasks assigned to the student.

$>\quad$ The lecturer is open to different ideas and perspectives. 
$>$ The lecturer gives prompt feedback.

$>\quad$ The lecturer applies rules consistently and lives up to the assessment methods used in the course.

$>\quad$ The lecturer is familiar with a variety of evaluation and assessment methods.

\section{Aspect 3: Classroom Management Skills}

\section{Primary Competencies}

$>\quad$ The lecturer is familiar with different parts of teaching-learning process.

$>\quad$ The lecturer varies teaching methods and content according to available resources.

$>\quad$ The lecturer ensures a learning environment where students can contribute their own inputs.

$>\quad$ The lecturer develops different learning strategies to respond to students' learning style differences.

$>\quad$ The lecturer uses written, audio-visual, and digital teaching aids to achieve the teaching goals.

$>\quad$ The lecturer adapts existing materials and expands these based on questions, suggestions, and examples from students.

$>\quad$ The lecturer employs different methods that recognize students' differences such as their different ways of learning, different levels, and different ways of working.

$>\quad$ The lecturer makes the content, form, structures, and relevance of the learning activity clear.

$>\quad$ The lecturer encourages students' cooperation and participation.

\section{Secondary Competencies}

$>\quad$ The lecturer is familiar with and considers students' different learning styles.

$>\quad$ The lecturer is familiar with the requirements of the course and applies various teaching methods.

$>\quad$ The lecturer challenges students to think about their own learning and development.

\section{Aspect 4: Professional Development Skills}

\section{Primary Competencies}

$>\quad$ The lecturer develops knowledge continuously by attending academic conferences or pedagogical courses.

$>\quad$ The lecturer seeks additional information on the subject being taught by reading journals or attending conferences.

$>\quad$ The lecturer engages in educational advancement and development.

$>\quad$ The lecturer participates in various teacher training courses.

The primary competencies are deemed necessary by a chemistry teacher to deliver the subject matter efficiently and effectively. The secondary competencies, on the other hand, are also important attributes but are just subservient of the primary competencies.

\section{Conclusion and Recommendations}

The present study identified desirable competencies of a Filipino chemistry teacher in terms of pedagogical skills, performance assessment skills, classroom management skills and professional development skills. Findings 
Espinosa, A. A., Nueva España, R. C., Datukan, J. T., Cortez, L. A. S., \& Tameta, A. D. C.

of the study can serve as a springboard in the development of a secondary chemistry teacher education curriculum in the Philippines. Moreover, chemistry education academics can benefit from the present study by focusing on the identified desirable competencies (transferrable skills) in the training of pre-service chemistry teachers. Since there are competencies that got a high rating in the surveys but did not transpire during the focus group, it is hereby recommended for future researchers to ask the academics and pre-service teachers why they think these competencies are important. Moreover, the study employed a limited number of respondents and participants only due to limited time and resources. A wider number of respondents and participants are hereby recommended to validate the result of the present study.

\section{References}

Commission on Higher Education (2007). Addendum to CMO 30 series of 2004: Revised policies and standards for undergraduate teacher education curriculum. Retrieved from http://www.ched.gov.ph/wp-content/uploads/2013/07/CMO-No.52-s2007.pdf

Commission on Higher Education (2007). Revised policies and standards for undergraduate teacher education curriculum. Retrieved from http://www.ched.gov.ph/wp-content/uploads/2013/07/CMO-No.30-s2004.pdf

Department of Education. (2006). National Competency-Based Teaching Standards (NCBTS). Manila: DepEd.

Department of Education. (2009). Department of Education Order No. 32 Series of 2009: National adoption and implementation of NCBTS-TSNA and IPPD for teachers, and integration of its system operations in the overall program for continuing teacher capacity building. Manila: DepEd.

Philippine National Research Center for Teacher Quality. (2016). Philippine professional standards for teachers. Retrieved from http://www.pnu.edu.ph/rctq/forms/professional-standards-for-teachers-in-the-philippines.pdf

Philippine Normal University Research Center for Teacher Quality. (2014). Developmental-national competency-based teacher standards. Retrieved from http://www.pnu.edu.ph/rctq/forms/D-NCBTS\%20FLyer\%20latest.pdf

Thawatchai, K. et al. (2014). Comparative study and development of teaching competency standards in 27 higher education level between faculty members and senior students among 5 ASEAN universities plus 28 one (China). Thailand: Suan Dusit Rajabhat University. 